\title{
Mortality and incidence of cancer among oil exposed workers in a Norwegian cable manufacturing company Part I Exposure conditions 1920-79
}

\author{
A RØNNEBERG, ${ }^{1}$ K SKYBERG ${ }^{2}$
}

From the Occupational Hygiene and Safety Department, ${ }^{1}$ Standard Telefon og Kabelfabrik A/S, PO Box 60 Økern, N-0508 Oslo 5, and Institute of Occupational Health, ${ }^{2}$ Oslo, and Medical Department, Standard Telefon og Kabelfabrik A/S, Oslo, Norway

\begin{abstract}
Heavy high viscosity oils, transformer oils, and very light low viscosity oils have been used in a Norwegian company in the impregnation, sheathing, and installation of paper insulated cables. The aim of the present study was to determine exposures to oils and other chemicals at these workplaces from 1920 to 1979 . Oil mist was sampled on glass fibre or membrane filters and analysed by infrared spectroscopy. Oil vapour concentrations were measured with a direct reading total hydrocarbon analyser with a flame ionisation detector. The results suggested average oil mist levels of $0.5-4 \mathrm{mg} / \mathrm{m}^{3}$ and oil vapour levels within $10-100 \mathrm{mg} / \mathrm{m}^{3}$. Definitive exposure to asbestos occurred in sheathing until the late 1950 s, whereas only minor exposure to asbestos took place in installation and impregnation.
\end{abstract}

Recent reviews have emphasised that the toxicological properties of mineral oil products may differ with their distillation and refining history, the crude petroleum from which they have been derived, and the types and amounts of additives present in the final product. ${ }^{-1}$ It has also been pointed out that the choice of methods and criteria for exposure assessment may depend on the boiling point range of the oil in question. ${ }^{56}$ Mineral oils of widely different boiling point ranges have been used by a Norwegian company for the impregnation of paper insulated power cables. The company's plant in Oslo has manufactured mass cables impregnated with waxy saturants based on heavy oils since the early 1920s, and oil filled cables impregnated with light oils since 1946. Exposure has taken place during the impregnation of paper insulated conductors in large vessels, the extrusion of cable jackets in metal sheathing presses, and the field installation of cable joints. Studies of respiratory disease and skin disorders among oil exposed workers at this plant have been reported elsewhere. ${ }^{78}$ The aim of the present study was to determine exposures to mineral oils and other chemicals in impregnation, sheathing, and installation in the period 1920-79. In another paper these data have been linked with mortality and incidence of cancer among workers employed during this period. ${ }^{9}$

Accepted 24 August 1987

\section{Historical information}

Mass cable saturants were made from viscous mineral oils and petroleum jelly from 1920 to 1940 and from transformer oils and colophony rosin from 1940 to 1945. Oil filled cables were impregnated with transformer oils from the start of production in 1946 until 1950. Table 1 shows all mass cable saturants and oil filled cable oils used since 1950, together with jointing oils used for impregnation of cable splices. Most of the base oils were derived from naphthenic crudes and had undergone only limited refining. They may be classified into three groups according to viscosity at $40^{\circ} \mathrm{C}$.

High viscosity oils $\left(500-2000 \mathrm{~mm}^{2} / \mathrm{s}\right)$ used in mass cable saturants $1920-40$ and $1945-79$ and as jointing oils 1946-79.

Transformer oils $\left(15-30 \mathrm{~mm}^{2} / \mathrm{s}\right)$ used in saturants $1940-45$, in oil filled cables $1945-50$, and as jointing oils 1941-71.

Low viscosity oils $\left(2-7 \mathrm{~mm}^{2} / \mathrm{s}\right)$ used in oil filled cables 1950-79. Kerosene used for cleaning of impregnation equipment from 1950 is chemically similar to the low viscosity oils.

The impregnation of mass cables and sheathing took place in two adjacent areas of a $1500 \mathrm{~m}^{2}$ factory hall, whereas oil filled cables were impregnated in two rooms of $100 \mathrm{~m}^{2}$ in the basement of the hall. Mass cable splicing in small jointing tents constituted most 
Table 1 Mineral oils used in paper insulated cable manufacture 1950-79*

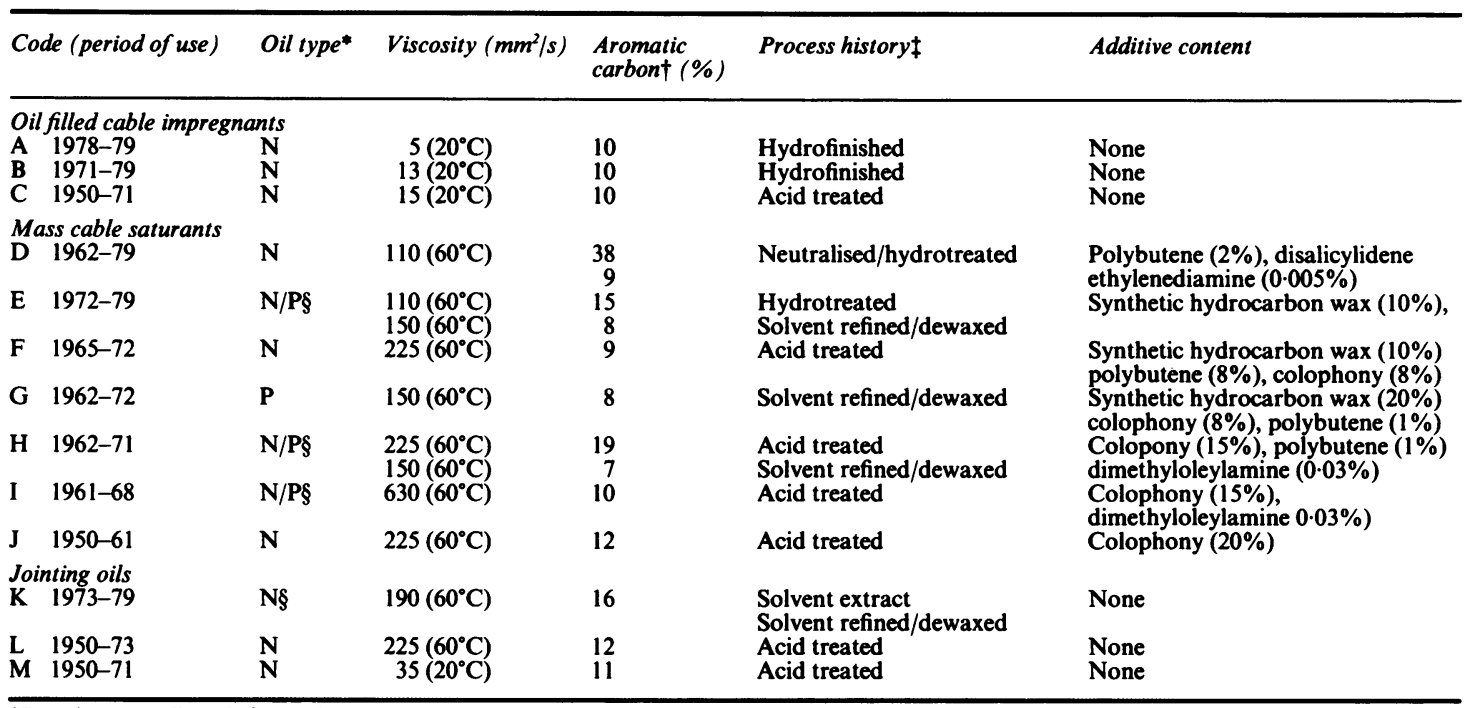

* Based on supplier's information.

†Determined by $n-d-m$ method.

$\ddagger$ All oils are clay treated.

\$The oil is a blend of two base oils.

$\mathbf{N}=$ Naphthenic

$\mathbf{P}=$ Paraffinic.

of the work in the installation department until the mid-1950s, when oil filled cable splicing in larger jointing houses became the major work task. High viscosity oils and transformer oils were generally used at temperatures of $100-120^{\circ} \mathrm{C}$ and low viscosity oils were used at $40-60^{\circ} \mathrm{C}$. Exposure to high viscosity oils occurred daily in impregnation, sheathing, and installation, whereas daily exposures to low viscosity oils and transformer oils occurred only in impregnation and installation.

Only small changes in facilities, equipment, and methods were implemented during the study period and no ventilation or personal protective equipment was used. Annual production volumes increased from the 1940s and reached a peak in the 1960s and 1970s. The frequency and duration of oil emitting operations in impregnation and sheathing were largely proportional to the production volumes and this may suggest that the highest exposures occurred in the 1960s and 1970s. In the installation department exposure levels were more independent of the production activity.

Asbestos powder of unknown type was mixed with water and used less than one hour every week until 1958 to maintain the insulation of one sheathing press. Steam pipelines and pumps in the impregnation area were insulated with materials containing chrysotile and amosite asbestos and the workers removed woven asbestos mats on a few occasions during maintenance work. In installation woven asbestos tape and asbestos board were used to protect the cable insulation during soldering for less than one hour a week.

\section{Material and methods}

The workroom air was contaminated by evaporation of oils at ambient or raised temperatures. Under such circumstances the saturation concentration of the oil vapours may be expected to approach that of the lower boiling constituents, since this fraction will evaporate selectively. Table 2 shows the boiling point ranges of the low viscosity oils $A$ and $B$ and high viscosity oil $K$ (table 1), together with volatility data for corresponding hydrocarbons. ${ }^{610}$ These data indicate that vapours of high viscosity oils will condense into an aerosol at concentrations above $0 \cdot 1 \mathrm{mg} / \mathrm{m}^{3}$ at normal workroom temperatures. Condensation of low viscosity oil vapour is unlikely to occur at levels below $100 \mathrm{mg} / \mathrm{m}^{3}$,

Table 2 Volatility data for high and low viscosity mineral oils

\begin{tabular}{llll}
\hline & $\begin{array}{l}\text { Vapour saturation } \\
\text { level of } \\
\text { constituents at } \\
20^{\circ} \mathrm{C}\left(\mathrm{mg} / \mathrm{m}^{3}\right) \dagger\end{array}$ & $\begin{array}{l}\text { Lifetime of a } 4 \mathrm{\mu m} \\
\text { oil particle in } \\
\text { pure air at } \\
20^{\circ} \mathrm{C}(\mathrm{s}) \dagger\end{array}$ \\
\hline Oil & $\begin{array}{l}\text { Boiling point } \\
\text { range }\left({ }^{\circ} \mathrm{C}\right)^{*}\end{array}$ & $45-2300$ & $0.2-7$ \\
$\mathrm{~A}$ & $215-285$ & $0.04-700$ & $2-6000$ \\
$\mathrm{~K}$ & $235-400$ & $\leqslant 0.04$ & $\geqslant 6000$ \\
\hline
\end{tabular}

* Determined by gas chromatography.

†Extrapolated from Davies. ${ }^{6}$ 
and any aerosol present may be expected to evaporate in the respiratory tract. ${ }^{6}$ Total aerosol and vapour concentrations may therefore be the appropriate criteria for assessing exposure to these low boiling oils.

Oil mist levels were determined from 1980 by fixed position or personal sampling on $37 \mathrm{~mm}$ glass fibre filters (Whatman GF/A) in closed face filter holders. Simultaneous sampling on mixed cellulose ester membrane filters (Millipore HAWP or GSWP) was included in some sample series. The amount of hydrocarbon in each sample was determined by double path infrared spectroscopy at $2940 \mathrm{~cm}^{-1}$ in 10 $\mathrm{mm}$ cells. The collected oil was extracted in tetrachloroethylene (Merck; spectroscopy grade) by ultrasound treatment and centrifugation, and volumes were adjusted to $10.0 \mathrm{ml}$. The solution was transferred to one of a matched pair of $10 \mathrm{~mm}$ cells and the other cell was filled with pure solvent. Five point standard curves were prepared for all oils from solutions of $0.25-1.25 \mathrm{mg}$ per $10.0 \mathrm{ml}$ and were linear within this range. Infrared analysis of three unused HAWP filters showed a content of $0.02 \mathrm{mg}$ extractable material with absorbance at $2940 \mathrm{~cm}^{-1}$ per filter, whereas no such material could be detected in three unused GF/A filters. This is consistent with previously reported data $^{10}$ and all results obtained with membrane filters were therefore corrected for a content of $0.02 \mathrm{mg}$ extractable material. In some sample series total dust concentrations were determined by gravimetric analysis of the membrane filters whereas this did not prove feasible for the more fragile glass fibre filters.

Total oil vapour and aerosol levels were measured from 1985 with a total hydrocarbon analyser (Model 710; Analytical Instrument Development, Inc) with a hydrogen flame ionisation detector. This instrument shows the detector's response to ionisable hydrocar- bons in the sample air as ppm methane equivalents (ppm ME) on a digital display. The 0.1-200.0 ppm scale with sensitivity $0.1 \mathrm{ppm}$ was used, and the instrument was zeroed with synthetic air ( $<3 \mathrm{ppm}$ ME hydrocarbons) and calibrated with $170 \mathrm{ppm}$ methane span gas. Workplace samples were taken from the breathing zone of the workers by recording the response in ppm ME several times during a process or work task. The natural methane level in a near-by, non-contaminated area was subtracted and no variation of more than $0.2 \mathrm{ppm}$ ME was detected during any of the measurements. Smoking or the use of flame torches or solvents was not permitted near the workplace during the measurements.

The total hydrocarbon analyser's response to mineral oil A (table 1) was determined by the following procedure. The instrument was connected to a dosimeter (Compur Minidosimeter 4102) which recorded the response once every second. The sample air flow rate was adjusted to $1.5 \pm 0.051 / \mathrm{min}$ and room air was metered for at least two minutes. About $15 \mathrm{ml}$ of mineral oil A was transferred to a $125 \mathrm{ml}$ gas washing bottle, leaving the inlet tube $1-2 \mathrm{~cm}$ above the surface to prevent pressure drop and aerosol formation. The bottle was weighed and connected to the sample probe of the instrument by means of a short Teflon hosing, and room air was sampled through the bottle for 30 to 120 minutes. Room air was sampled directly for another two minutes while the bottle was reweighed. The average oil concentration was calculated in $\mathrm{mg} / \mathrm{m}^{3}$ from the weight loss and the sample air volume and in ppm ME from the dosimeter printout after subtraction of the average methane background. Based on four experiments, the instrument's response to oil vapours was calculated to 4.0 $\mathrm{mg} / \mathrm{m}^{3}$ per $\mathrm{ppm} \mathrm{ME} \mathrm{(standard} \mathrm{deviation} 8 \%$ ).

Table 3 Oil mist measurements during cable manufacture 1980-5

\begin{tabular}{|c|c|c|c|c|c|c|c|}
\hline \multicolumn{2}{|c|}{$\begin{array}{l}\text { Sample series No } \\
\text { and location }\end{array}$} & \multirow{2}{*}{$\begin{array}{l}\text { No of samples } \\
\frac{6}{11}\end{array}$} & \multirow{2}{*}{$\begin{array}{l}\text { Filter type* } \\
\text { GF/A, P } \\
\text { GF/A, P }\end{array}$} & \multirow{2}{*}{$\begin{array}{l}\begin{array}{l}\text { Sampling period } \\
(\text { min })\end{array} \\
480 \\
480\end{array}$} & \multirow{2}{*}{$\frac{\text { Flow rate }(l / \mathrm{min})}{2}$} & \multirow{2}{*}{$\begin{array}{l}\begin{array}{l}\text { Total dust level } \dagger \\
\left(\mathrm{mg} / \mathrm{m}^{3}\right)\end{array} \\
-\end{array}$} & \multirow{2}{*}{$\begin{array}{l}\begin{array}{l}\text { Oil mist level } \\
\left(\mathrm{mg} / \mathrm{m}^{3} \pm S D\right.\end{array} \\
0 \cdot 2 \pm 0 \cdot 1 \\
0 \cdot 3 \pm 0 \cdot 1\end{array}$} \\
\hline 1 & $\begin{array}{l}\text { Impregnation } \\
\text { Sheathing }\end{array}$ & & & & & & \\
\hline 2 & Impregnation & 6 & GF/A, F & 20 & $15-20$ & - & $0.6 \pm 0.4$ \\
\hline 3 & Impregnation & $\begin{array}{l}5 \\
5\end{array}$ & $\begin{array}{l}\text { GF/A, F } \\
\text { HAWP, F }\end{array}$ & $\begin{array}{l}265 \\
265\end{array}$ & $\begin{array}{l}1.35 \\
0.25\end{array}$ & - & $\begin{array}{l}0.1 \pm 0.1 \\
0.9 \pm 0.1\end{array}$ \\
\hline \multirow[t]{3}{*}{4} & Installation & $\begin{array}{l}2 \\
1\end{array}$ & $\begin{array}{l}\text { GF/A, F } \\
\text { GSWP, F }\end{array}$ & $\begin{array}{l}80 \\
80\end{array}$ & $\begin{array}{l}2 \\
1\end{array}$ & $\overline{7 \cdot 4}$ & $\begin{array}{l}0 \cdot 9 \\
4 \cdot 3\end{array}$ \\
\hline & & $\begin{array}{l}2 \\
2\end{array}$ & $\begin{array}{l}\text { GF/A, F } \\
\text { GSWP, F }\end{array}$ & $\begin{array}{l}50 \\
50\end{array}$ & $\begin{array}{l}15-22 \\
11\end{array}$ & $\overline{0.9}$ & $\begin{array}{l}0 \cdot 3 \\
0.5\end{array}$ \\
\hline & & $\begin{array}{l}3 \\
3\end{array}$ & $\begin{array}{l}\text { GF/A, F } \\
\text { GSWP, F }\end{array}$ & $\begin{array}{l}15-25 \\
15-25\end{array}$ & $\begin{array}{l}14-20 \\
10-14\end{array}$ & $\frac{-}{3 \cdot 4}$ & $\begin{array}{l}1.3 \pm 0.5 \\
1.8 \pm 0.2\end{array}$ \\
\hline
\end{tabular}

*GF/A = Whatman GF/A glass fibre filter, HAWP = millipore HAWP membrane filter, GSWP = millipore GSWP membrane filter, P $=$ personal sampling, $\mathrm{F}=$ fixed position sampling.

†etermined by gravimetric analysis of membrane filters, GF/A filters too fragile to be analysed by gravimetry. $\ddagger$ Determined by infrared analysis; results obtained with membrane filters corrected for a content of 0.02 mg extractable organic material per
filter. 


\section{Results}

Table 3 shows the results of oil mist measurement during impregnation, sheathing, and installation in 1980-2. The samples were collected under work conditions typical of those present during the 1960s and 1970s. Personal eight hour and short term fixed position samples were collected on glass fibre filters in impregnation and sheathing on six days in summer. Saturants D and E (table 1) were used. Time weighted average (TWA) oil mist levels were measured to $\mathbf{0 . 2}$ $\mathrm{mg} / \mathrm{m}^{3}$ in the impregnation area and $0.3 \mathrm{mg} / \mathrm{m}^{3}$ in the sheathing area (sample series 1 ). The fixed position samples showed a short term level of $0.6 \mathrm{mg} / \mathrm{m}^{3}$ during processes which emitted large amounts of oil mist and vapours (sample series 2 ).

A sampling device that allowed simultaneous sampling on five glass fibre filters and five HAWP membrane filters was used in one experiment (sample series 3). Filter holders were spaced less than $0.3 \mathrm{~m}$ apart and the device was placed more than $10 \mathrm{~m}$ from any source of oil mist in the impregnation hall. Working conditions were similar to those present during the measurements described above. The oil mist concentration was determined to $0.1 \mathrm{mg} / \mathrm{m}^{3}$ by sampling on glass fibre filters, whereas sampling on membrane filters showed a concentration of $0.9 \mathrm{mg}$ / $\mathrm{m}^{3}$.

Oil mist was also collected by fixed position sampling during oil filled cable splicing in a typical, unventilated jointing house (sample series 4). The cable was impregnated with low viscosity oil $B$ and a heater with a $1: 1$ blend of this oil and oil $\mathrm{K}$ at $120^{\circ} \mathrm{C}$ was placed within the jointing house. The aerosol was sampled simultaneously on glass fibre and GSWP membrane filters placed less than $10 \mathrm{~cm}$ apart. Oil mist levels were measured to $0.3-1.3 \mathrm{mg} / \mathrm{m}^{3}$ by sampling on glass fibre filters, and to $0.5-4 \cdot 3 \mathrm{mg} / \mathrm{m}^{3}$ by sampling on membrane filters. The weight increase of the membrane filters was higher than the amount of oil determined by infrared analysis.

Total oil levels were monitored with the total hydrocarbon analyser during installation of oil filled cables impregnated with oil A and mass cables impregnated with saturant $D$ in 1985 and 1986; the results are shown in table 4. TWA exposure levels were measured to $17 \mathrm{mg} / \mathrm{m}^{3}$ (range $4-48$ ) and $32 \mathrm{mg} / \mathrm{m}^{3}$ (range 12-60) in two unventilated jointing houses typical of those used since the 1950s. TWA levels of $13 \mathrm{mg} / \mathrm{m}^{3}$ (range 8-52) were measured in a jointing house with a mechanical fresh air supply. TWA levels during oil filled or mass cable installation inside ventilated halls were $5 \mathrm{mg} / \mathrm{m}^{3}$ (range 1-40). No total oil measurement has been performed in impregnation or sheathing. Only a single hydrocarbon vapour measurement, however, was carried out during cleaning of hot impregnation equipment with kerosene in 1979. A colorimetric indicator tube (Dräger $\mathrm{CH} 25401$ ) connected to a hand operated pump was used, showing a short term level of $2000-4000 \mathrm{mg} / \mathrm{m}^{3}$

\section{Discussion}

Many different methods for sampling and analysis have been used in previous epidemiological studies of exposure to oil mist. ${ }^{11-14}$ In some reports results obtained by sampling in gas washing bottles are presented as oil mist concentrations, ${ }^{1516}$ although this sampling method might be expected to collect the vapour phase as well. The results presented here show that different methods for determining oil mist levels may yield very different results. In particular, it is notable that consistently lower results were obtained with glass fibre filters than with membrane filters after simultaneous sampling (table 3). The collection efficiency of the GF/A filter is $99.8 \%$ for a $0.3 \mu \mathrm{m}$ aerosol at a sample air flow rate of $171 / \mathrm{min},{ }^{17}$ but much lower flow rates were used during some of the present measurements. If the sample air velocity at the filter face is decreased sufficiently the particle collection efficiency may be expected to approach that observed in liquid phase filtration. The effective void sizes of the GSWP and HAWP membrane filters for filtration of liquids are 0.22 and $0.45 \mu \mathrm{m}$, respectively, ${ }^{17}$ as compared with $1.5 \mu \mathrm{m}$ for the GF/A filter. ${ }^{10}$ Volume median particle diameters of $0.4-0.6 \mu \mathrm{m}$ have been

Table 4 Total oil measurements* during paper insulated cable installation $1985-7\left(\mathrm{mg} / \mathrm{m}^{3}\right)$

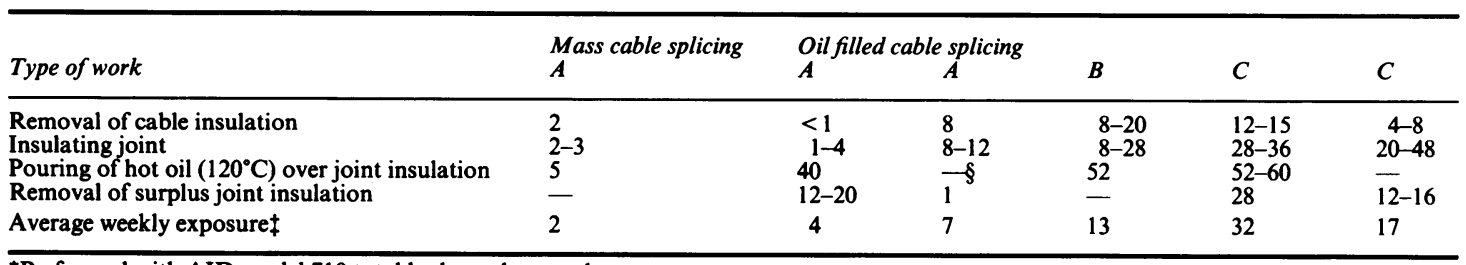

*Performed with AID model 710 total hydrocarbon analyser.

$\dagger \mathbf{A}=$ ventilated hall, $\mathbf{B}=$ ventilated jointing house, $\mathbf{C}=$ unventilated jointing house

¥Calculated from the measured concentrations and the duration of each work task during one 40 hour weeks work on each type of installation. $\S$ The work task was not performed during this installation. 
reported in oil mist formed by condensation. ${ }^{18}$ Filter penetration may therefore provide a possible explanation of the present results.

Based on the assumption that an acceptable accuracy has been obtained with the membrane filters, the collection efficiency of the glass fibre filter during the present measurements might be estimated to $25 \%$ at flow rates of $1-21 / \mathrm{min}$ and to at least $50 \%$ at flow rates of $10 \mathrm{l} / \mathrm{min}$ or more. Additional errors, however, may also be present in the oil mist measurements. Some samples could only be quantified by assuming linearity of the standard curve from $0.03 \mathrm{mg}$ oil per 10 $\mathrm{ml}$ as compared with $0.25 \mathrm{mg}$ in the most dilute standard solution. Estimates of extractable organic material in the filters were based on analysis of very few blank filters. Finally, it cannot be ruled out that condensation of low viscosity oil vapours may have occurred. Results from the oil mist measurements must therefore be interpreted as high estimates of the high viscosity oil mist levels. With these reservations, the results presented here may suggest that TWA levels of high viscosity oil mist were $0.5-1.5 \mathrm{mg} / \mathrm{m}^{3}$ in the impregnation and sheathing area and $1-4 \mathrm{mg} / \mathrm{m}^{3}$ at a typical installation site.

Results obtained with the total hydrocarbon analyser may be interpreted as low viscosity oil concentrations, since the much less volatile high viscosity oils have probably not contributed significantly. These results suffer from a poor precision, which is unavoidable when using a direct reading instrument to estimate TWA concentrations. Measurements at several installation sites (table 4) suggest levels of $25-40 \mathrm{mg} / \mathrm{m}^{3}$ in unventilated jointing houses and $3-10 \mathrm{mg} / \mathrm{m}^{3}$ in larger halls. Most of the work has been performed at the former type of workplace and the cable splicers may be assumed to have been exposed to TWA levels within $10-50 \mathrm{mg} / \mathrm{m}^{3}$.

No measurement of total oil levels has been performed in impregnation. Exposure occurred mainly during oil filled cable impregnation and cleaning of hot equipment with kerosene. Nausea, loss of smell, slight intoxication, and respiratory irritation were common complaints during this work and the occurrence of these symptoms may suggest low viscosity oil vapour levels above $3500 \mathrm{mg} / \mathrm{m}^{3} .^{1920}$ This assumption is supported by the result obtained with a colorimetric tube during this work. An estimated TWA level of $50-100 \mathrm{mg} / \mathrm{m}^{3}$ may be calculated from the time spent by the impregnation workers in this work.

The available information on use of asbestos indicates that definitive exposure to asbestos occurred in sheathing until the late 1950s, whereas only minor exposures took place in installation and impregnation. A radiological investigation of all 25 active impregnation and sheathing workers with at least five years employment and 25 referents matched by age and sex was performed in $1980 .{ }^{8}$ The mean employment period of the exposed workers was 17.5 years (range 5-35) and the mean age was 48.6 years (range 22-67). Full size chest radiographs were evaluated independently by two radiologists. One radiologist described pleural thickening or other minor pleural changes in two impregnation workers $(14 \%)$, five sheathing workers $(45 \%)$, and two referents $(8 \%)$. whereas the other radiologist described such changes in one impregnation and one sheathing worker and in one referent. There was no case of pleural calcification. An investigation of full size chest radiographs of workers in a Gothenburg shipyard showed pleural plaques in $\mathbf{4 0 \%}$ of 102 office workers (mean age 54.6 years). ${ }^{21}$ The diagnostic criteria used in the cable worker study ${ }^{8}$ were not stated, however, and this makes it difficult to compare these findings.

At the Institute of Occupational Health, Oslo, we are grateful to Bjørn Gylseth for valuable advice in the preparation of this report and Jack R Pedersen for analysis of the oil mist samples.

\section{References}

1 Bingham E, Trosset RP, Warshawsky D. Carcinogenic potential of petroleum hydrocarbons. J Environ Pathol Toxicol 1980;3:483-563.

2 The oil companies' international study group for conservation of clean air and water-Europe. Health aspects of lubricants. The Hague: CONCAWE, 1983, (Rep No 1/83).

3 International Agency for Research on Cancer. Monographs on the evaluation of the carcinogenic risk of chemicals to man. Polynuclear aromatic hydrocarbons. Part 2. Carbon blacks, mineral oils and some nitroarenes. Lyon: IARC, 1984.

4 International Programme on Chemical Safety. Selected petroleum products. (Environmental health criteria 20.) Geneva: World Health Organisation, 1982.

5 The oil companies' international study group for conservation of clean air and water-Europe. Guidelines for the determination of atmospheric concentrations of oil mists. The Hague: CONCAWE, 1981, (Rep No 1/81).

6 Davies CN. Atmospheric concentrations of oil mist. Ann Occup Hyg 1977;20:91-2.

7 Skyberg K, Rønneberg A. Skin disorders among cable workers exposed to mineral oils. Tidsskr Nor Lageforen 1986;106:657-9. (In Norwegian.)

8 Skyberg K, Rønneberg A, Kamøy JI, Dale K, Borgersen A. Pulmonary fibrosis in cable plant workers exposed to mist and vapor of petroleum distillates. Environ Res 1986;40:261-73.

9 Rønneberg A, Andersen A, Skyberg K. Mortality and incidence of cancer among oil exposed workers in a Norwegian cable manufacturing company. Part 2. Mortality and cancer incidence 1953-84. Br J Ind Med 1988;45:595-601.

10 Berg H, Fallentin B, Haunsøe N, et al. Changes in coolantlubricants during use. Health- and hygiene-related problems. Tảstup: Teknologisk Instituts Forlag, 1979. (In Danish.)

11 Cullen MR, Balmes JR, Robins JM, Smith GJW. Lipoid pneumonia caused by oil mist exposure from a steel rolling tandem mill. Am J Ind Med 1981;2:51-8.

12 Ely TS, Pedley SF, Hearne FT, Stille WT. A study of mortality, 
symptoms, and respiratory function in humans occupationally exposed to oil mist. J Occup Med 1970;12:253-61.

13 Järvholm B, Lillienberg L, Sällsten G, Thiringer G, Axelson O. Cancer morbidity among men exposed to oil mist in the metal industry. J Occup Med 1981;23:333-7.

14 Pasternak B, Ehrlich L. Occupational exposure to an oil mist atmosphere. Arch Environ Health 1972;25:286-94.

15 Drasche H, Finzel L, Martchei N, Meyer R. Arbeitsmedizinische erhebungen bein ölnebelexponierten personen. Zentralblatt für Arbeitsmedizin 1974;10:305-12.

16 Jones JG. An investigation into the effects of exposure to an oil mist on workers in a mill for the cold reduction of steel strip. Ann Occup Hyg 1961;3:264-71.

17 American Public Health Association Intersociety Committee. Filter media for air sampling. In: Katz M ed. Methods of air sampling and analysis. 2nd ed. Washington: APHA Publication office, 1977.

18 Alenius S, Höjerdal P. The efficiency of oil mist collectors-III Oil mist collectors in the industry. Arbete och halsa No 5/83. Stockholm: Arbetarskyddsverket, 1983.

19 Carpenter CP, Geary DL, Myers RC, Nachreiner DL, Sullivan LJ, King JM. Petroleum hydrocarbon toxicity studies-XI. Animal and human response to vapors of deodorized kerosene. Toxicol Appl Pharmacol 1976;36:443-56.

20 Knave B, Persson HE, Goldberg JM, Westerholm P. Long-term exposure to jet fuel. An investigation of occupationally exposed workers with special reference to the nervous system. Scand J Work Environ Health 1976;3:152-64.

21 Järvholm B, Sandén A. Estimating asbestos exposure: a comparison of methods. J Occup Med 1987;29:361-3.

\section{Vancouver style}

All manuscripts submitted to the $\mathrm{Br} J$ Ind Med should conform to the uniform requirements for manuscripts submitted to biomedical journals (known as the Vancouver style)

The $\mathrm{Br} J$ Ind Med, together with many other international biomedical journals, has agreed to accept articles prepared in accordance with the Vancouver style. The style (described in full in $\mathrm{Br}$ Med J, 24 February 1979, p 532) is intended to standardise requirements for authors.

References should be numbered consecutively in the order in which they are first mentioned in the text by Arabic numerals above the line on each occasion the reference is cited (Manson ${ }^{1}$ confirmed other reports ${ }^{2-5} \ldots$.). In future references to papers submitted to the $\mathrm{Br} J$ Ind Med should include: the names of all authors if there are six or less or, if there are more, the first three followed by et al; the title of journal articles or book chapters; the titles of journals abbreviated according to the style of Index Medicus; and the first and final page numbers of the article or chapter.

Examples of common forms of references are:

I International Steering Committee of Medical Editors. Uniform requirements for manuscripts submitted to biomedical journals. Br Med J 1979;1:532-5.

2 Soter NA, Wasserman SI, Austen KF. Cold urticaria: release into the circulation of histamine and eosino-phil chemotactic factor of anaphylaxis during cold challenge. $N$ Engl $J$ Med 1976;294:687-90.

3 Weinstein L, Swartz MN. Pathogenic properties of invading micro-organisms. In: Sodeman WA Jr, Sodeman WA, eds. Pathologic physiology: mechanisms of disease. Philadelphia: W B Saunders, 1974:457-72. 